\title{
Influence of drought stress on afalfa yields and nutritional composition
}

Yinghao Liu', Qian Wu', Gentu Ge1, Guodong Han ${ }^{1}$ and Yushan Jia ${ }^{1,2,3^{*}}$

\begin{abstract}
Background: It is predicted that climate change may increase the risk of local droughts, with severe consequences for agricultural practices.

Methods: Here we report the influence of drought on alfalfa yields and nutritional composition, based on artificially induced drought conditions during two field experiments. Two types of alfalfa cultivars were compared, Gold Queen and Suntory. The severity and timing of drought periods were varied, and the crop was harvested either early during flowering, or late at full bloom.

Results: The obtained dry mass yields of Gold Queen were higher than Suntory, and the first was also more resistant to drought. Early harvest resulted in higher yields. Decreases in yields due to water shortage were observed with both cultivars, and the fraction of crude protein (CP) decreased as a result of drought stress; this fraction was higher in Gold Queen than in Suntory and higher in early harvest compared to late harvest. Severe drought late in spring had the highest effect on CP content. The fraction of fibre, split up into neutral detergent fibre (NDF) and acid detergent fibre (ADF) increased as a result of drought and was lower in early compared to late harvested plants. Suntory alfalfa produced higher fibre fractions than Gold Queen. The fraction of water-soluble carbohydrates (WSC) was least affected by drought. It was consistently higher in Gold Queen compared to Suntory alfalfa, and late harvest resulted in higher WSC content.
\end{abstract}

Conclusions: In combination, these results suggest that the nutritive value of alfalfa will likely decrease after a period of drought. These effects can be partly overcome by choosing the Gold Queen cultivar over Suntory, by targeted irrigation, in particular in late spring, and by harvesting at an earlier time.

Keywords: Alfalfa (Medicago sativa L.), Drought stress, Water regimes, Nutritive value

\section{Background}

Grassland remains an important feed source for ruminant nutrition, with its high productivity and good fodder quality [1], but alfalfa is often a necessary feed additive or alternative, especially suitable for feed production under nitrogen-limiting conditions, due to the plant's ability to fix atmospheric $\mathrm{N}_{2}$ [2]. With the increase of energy costs, fertiliser (as an artificial source of soil $\mathrm{N}$ ) has become more expensive, a trend that is expected to continue in the future, which will likely further increase

\footnotetext{
* Correspondence: 610480018@qq.com

${ }^{1}$ Key Laboratory of Forage Cultivation, Processing and High Efficient Utilization, Ministry of Agriculture, Erdos Street 29, Saihan District, Hohhot 010019, China

2Laboratory of Grassland Resources, Ministry of Education, Erdos Street 29,

Saihan District, Hohhot 010019, China

Full list of author information is available at the end of the article
}

the need of legume production, including alfalfa $[3,4]$. Agricultural forage production depends on an adequate water supply [5], a dependence that can become problematic in semi-arid climates, especially where local effects due to climate change increase the probability of summer droughts [6-8]. Insufficient water supply can strongly affect the production of forage legumes [9], resulting in decreasing yields, depending on the severity and duration of drought stress $[10,11]$.

It is well known that forage legumes differ in drought stress sensitivity [12]. White clover is one of the most important legumes in agricultural production, but it is also relatively drought sensitive [13]. Drought stress can have variable effects on plant content. Under drought conditions, concentrations of acid detergent fibre (ADF) and neutral detergent fibre (NDF) were reduced in a 
range of forage legumes, while inconsistent changes were reported in crude protein $(\mathrm{CP})$ concentrations [14]. Another study reported an increase in water-soluble carbohydrates (WSC) under water shortage in two cultivars of soybean [15], while for clover species only a small drought-induced effect on WSC was observed [16]. One study described an increase in ADF with a minor effect only for $\mathrm{CP}$ and NDF concentrations in red clover and alfalfa [17]. However, there is limited and inconsistent knowledge available about the influence of drought stress on the nutritive value of alfalfa. This legume is possibly less sensitive to drought than white clover, but more research is needed to predict the influence of drought stress on the nutritive value of alfalfa, which was one of the aims of this study.

Alfalfa was used here to examine the effects of drought stress on the concentrations of $\mathrm{CP}, \mathrm{WSC}$ and the fibre components NDF and ADF, which were chosen as indicators for nutritive value. The $\mathrm{CP}$ concentration is an essential component for ruminant nutrition, and is typically high in alfalfa due to effective N fixation; WSC have a positive influence on fodder intake and are important for an efficient utilisation of dietary N; NDF content provides an estimate of the cellulose, hemicellulose and lignin content and is inversely related to voluntary fodder intake; finally ADF includes lignin and cellulose and is negatively correlated with cell wall digestibility [18]. In the present study the following questions were addressed: (1) do different alfalfa species differ in their response to drought stress; and (2) what is the effect of timing, duration, and intensity of water restriction on the nutritional parameters of alfalfa.

\section{Methods}

\section{Field experiments}

A field study was conducted in 2012-2014 in a vegetation area of Ar Horqin Banner near the Nei Monggol Autonomous Region, China (coordinates $37^{\circ} 43^{\prime} \mathrm{N} ; 120^{\circ}$ $22^{\prime} \mathrm{E}$ ), using a randomized block design with three variable parameters that were tested with four replications. Two types of alfalfa were compared: Gold Queen and Suntory alfalfa. Conditions resembling severe draught and moderate draught were compared with optimal water supply whereby the timing of water restriction was varied. The plants were either harvested early during initial flowering, or late during full bloom. Details about the applied water regimes are described in Table 1 . Drought stress was imposed during three periods with variable severity. The trials were divided into two experiments. In Experiment I (2013, spring through summer, sowing date 23 July 2012, final harvest date 14 September 2013), three restricted water supply regimes were compared to the optimal water supply control: severe drought stress during spring, and moderate and
Table 1 The applied water regimes during field experiments and the yields of early and late harvest

\begin{tabular}{llll}
\hline & $\begin{array}{l}\text { Water regime, } \\
\text { condition nr. }\end{array}$ & $\begin{array}{l}\text { Early yield } \\
\text { DM (t/ha) }\end{array}$ & $\begin{array}{c}\text { Late yield } \\
\text { DM (t/ha) }\end{array}$ \\
\hline Experiment I (2013) & $\begin{array}{l}\text { Optimal, control } \\
\text { Moderate drought }\end{array}$ & 13.1 & 12.7 \\
& $\begin{array}{l}12.1 \\
\text { in spring } \\
\text { Severe drought in } \\
\text { spring }\end{array}$ & 11.4 & 12.0 \\
& $\begin{array}{l}\text { Moderate drought } \\
\text { in summer } \\
\text { Severe drought in } \\
\text { Experiment II (2014) }\end{array}$ & 11.7 & 11.0 \\
& $\begin{array}{l}\text { Optimal, control } \\
\text { Severe drought in } \\
\text { early spring } \\
\text { Severe drought in } \\
\text { late spring }\end{array}$ & 11.1 & 12.3 \\
& 10.1 & 12.7 \\
Rainfed & 11.1 & 10.5 \\
\hline
\end{tabular}

severe drought stress during summer. Moderate stress corresponded with $20-40 \%$ usable water capacity of the soil and severe stress corresponded to only $10-15 \%$. In Experiment II, conducted a year later (sowing date 16 August 2013, final harvest date 21 September 2014), severe water restriction (15\% available water) was applied either in early spring or in late spring, and this was compared to rain fed and optimally watered plots.

Drought stress was implemented by restricting rain precipitation on individual plots, using a $12 \mathrm{~m}$ long, $6 \mathrm{~m}$ wide, and $5 \mathrm{~m}$ high foil cover (CASADO, Dou-ville, France). This stationary shelter was covered by $200-\mu \mathrm{m}$ polythene foil, which was mounted over the plot. In order to attain good ventilation and to minimize microclimate effects of the shelter, the front and the sides were left open.

\section{Alfalfa types}

Gold Queen alfalfa is a novel American cultivar, marketed as a salt-tolerant type that is suitable for high saline-alkali soil. Suntory alfalfa is a French cultivar with a high yield of high quality and is known to be disease-resistant.

The seeds were kindly provided by the College of Agriculture and Animal Husbandry, ChiFeng, China. The seeding density was $0.5 \mathrm{~kg}$ seed per $0.667 \mathrm{hm}^{2}$ and plot sizes ranged from 6.6 to $8.2 \mathrm{~m}^{2}$.

\section{Climate conditions}

Air temperature and precipitation were recorded at $2 \mathrm{~m}$ height with an iMETOS weather station (Pessl Instruments, Weiz, Austria) located on the experimental site. The agrometeorological advisory system from the China Weather Service (CWS, 2014) was used to plan the irrigation schedule. 


\section{Soil composition and water content}

The soil was characterized as Haplic Luvisol with an available water capacity of $120 \mathrm{~mm}(0-90 \mathrm{~cm})$, and a groundwater level $10 \mathrm{~m}$ below surface. The soil was composed of $36 \%$ corn soil, $27 \%$ sand, $12 \%$ chernozem and $5 \%$ of other components. The $\mathrm{pH}$ of the soil (in $\mathrm{CaCl}_{2}$ suspension) measured in summer 2013 was 7.3. The soil moisture was recorded during the experiments using a portable soil moisture probe Diviner 2000 (Santé Technologies, Stepney, Australia). Plastic tubes with a diameter of $5 \mathrm{~cm}$ were installed to a depth of up to $150 \mathrm{~cm}$. Soil moisture readings were taken at $10 \mathrm{~cm}$ intervals from 5 to $125 \mathrm{~cm}$ three times per week from the beginning of vegetation to harvest. The soil water content was also determined gravimetrically on several occasions in order to obtain a site-specific calibration $\left(R^{2}=0.64\right)$. The soil moisture data over time are presented as precentage, calculated as $\mathrm{ml} / 100 \mathrm{~g}$ soil.

\section{Sampling and measurements}

For each experiment the plots were harvested by hand. For harvests, over an area of $0.09 \mathrm{~m}^{2}$ in Experiment 1, and $0.18 \mathrm{~m}^{2}$ in Experiment 2 per plot, the plants were cut at a height of 3-4 $\mathrm{cm}$ above the soil surface and cuttings were separated from weeds immediately after harvest. Dry weight of alfalfa harvest was determined after drying at $60{ }^{\circ} \mathrm{C}$ for $72 \mathrm{~h}$ in a drying oven (ULM 800, Member GmbH, Schwa Bach, Germany).

For analysis of CP, NDF, ADF and WSC, dried samples were ground to $1 \mathrm{~mm}$ particles and these were analysed by near-infrared reflectance spectroscopy (NIRS). All findings are reported as \% dry mass (\%DM). The spectra were analysed using a large dataset of calibration samples from different kinds of grasslands available from the Institute VDLUFA Qualitätssicherung NIRS GmbH, Kassel, Germany.

\section{Statistical analyses}

Analyses of variance were carried out with the GLIMMIX procedure of SAS 9.3 (SAS Institute, Cary, NC, USA). We performed a three factorial analysis of variance (ANOVA) for CP, NDF, ADF and WSC concentrations of the two cultivars for the two harvests [19]. The three factors were legume cultivar (LS), flowering phase (FS) and drought stress (DS). Relationships between selected variables were examined with a linear regression model. Experiment I and II as well as individual years were analyzed separately. Correlations were calculated with the CORR procedure of SAS. Graphs were created with SigmaPlot 12 (Systat Software Inc., Chicago, IL, USA).

\section{Results}

In the two field experiments, conducted in two consecutive years, the two cultivars Gold Queen and Suntory alfalfa were subjected to various levels of drought. The plants were harvested at two developmental stages. In Experiment I, conducted in 2013, two drought levels were simulated during spring and two during summer (moderate spring drought, severe spring drought, moderate summer drought and severe summer drought); optimally watered plots served as control. In Experiment II, conducted a year later, severe drought was implemented either in early spring or in late spring, while optimal watering (control) was also compared to natural rainfall without further irrigation (rainfed). In both experiments, for all conditions, half of the plots were harvested early, during the initial blooming phase, and the other half was harvested later, at full blooming stage. The conditions tested are summarized in Table 1. All plots within one experiment were harvested at the same time, and the harvested alfalfa was chemically analyzed for a number of nutritional variables.

Figure 1 shows the relative available water in the soil during the various treatments of experiment I (2013) and of the treatments during experiment II (2014).

A graph showing local precipitation and temperature during the experiments is available as Additional file 1: Figure S1. In 2013, spring was warm and dry while summer temperatures were moderate. Yearly total rainfall amounted to $224 \mathrm{~mm}$ with an average temperature of $16.9{ }^{\circ} \mathrm{C}$ (Additional file 1: Figure S1). The year 2014 started with low temperatures, followed by a cool spring, with total rainfall $(327 \mathrm{~mm})$ and average air temperature $\left(15.7^{\circ} \mathrm{C}\right)$ lower than in 2013 . The beginning of 2014 was relatively cool, which delayed vegetation development, while May was unusually wet with over $100 \mathrm{~mm}$ rainfall (Additional file 1: Figure S1).

The alfalfa early and late yields in $\mathrm{t} / \mathrm{ha}$, after removal of weeds and after drying (dry mass, DM), are shown in Table 1.

\section{Crude protein concentration}

Crude protein concentrations from the harvested alfalfa were determined and expressed as percentage of dry mass (\% DM) (Table 2). Whereas moderate drought applied during the spring of 2013 had no significant effect on $\mathrm{CP}$ concentration, severe spring drought resulted in significantly lower $\mathrm{CP}$ values compared to optimally watered controls, for both alfalfa types, and for both harvest times (Table 2). ANOVA statistical analysis indicated there was a significant difference $(P<0.001)$ for $\mathrm{CP}$ content between the compared cultivars, with Gold Queen alfalfa producing significantly higher CP contents under all conditions tested. Early harvest produced significantly higher yields than late harvests, for both cultivars. The overall range of $\mathrm{CP}$ content of alfalfa grown with drought stress during spring varied between 15.61 and $17.61 \%$ DM. When drought stress was applied 

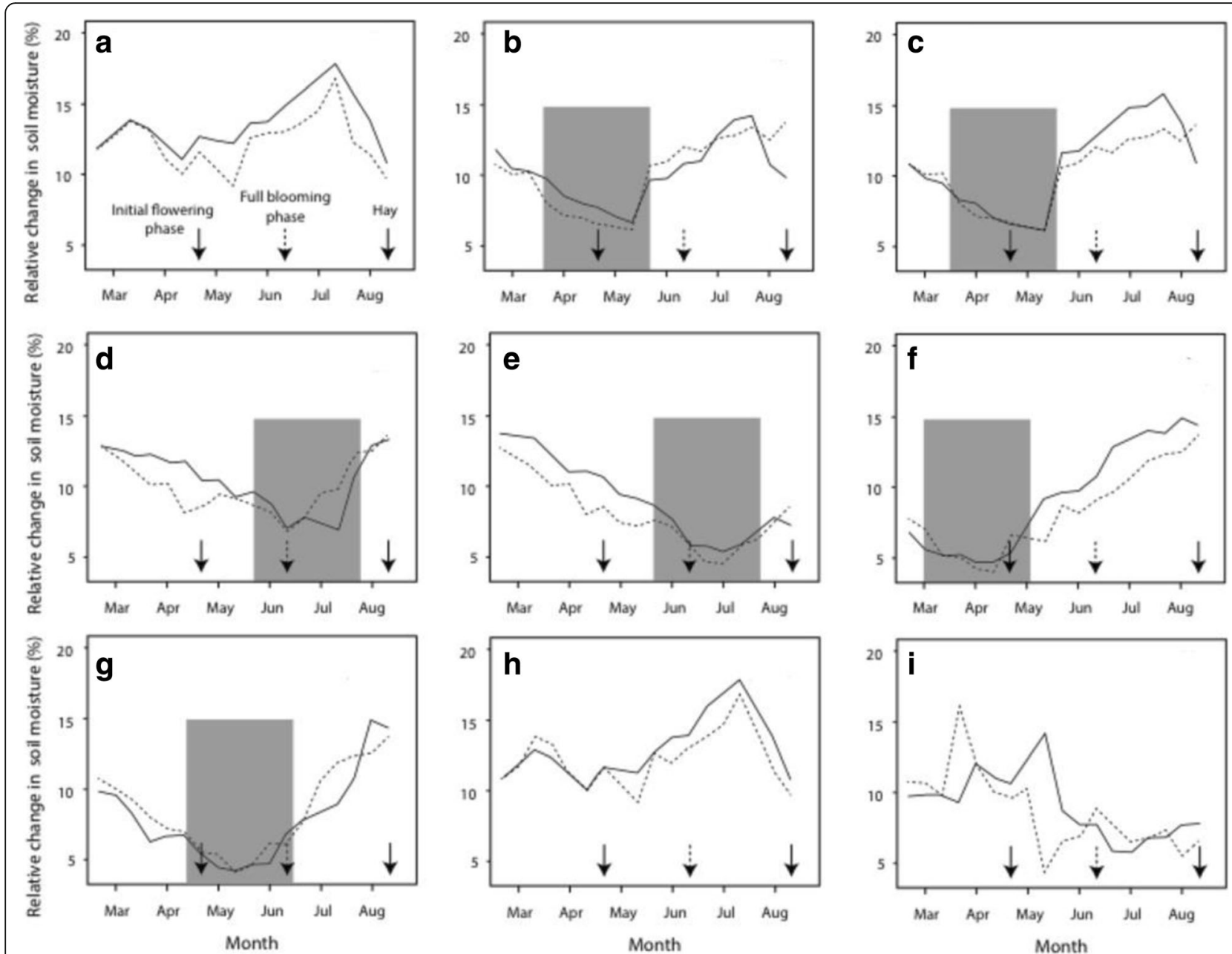

Fig. 1 Soil moisture levels ( $\mathrm{ml}$ water/100 mg soil) over time for optimally watered control (a) and experimental conditions during Experiment 1 of moderate spring drought (b), severe spring drought (c), moderate summer drought (d) and severe summer drought (e), and for the experimental conditions of Experiment 2 corresponding to early spring severe drought (f), late spring severe drought (g), rainfed (h) and control (i). In each plot, two average moisture levels of four individual plots are shown, for those harvested early (solid lines) and late (dotted lines). The periods of artificially induced drought are indicated in grey. The three arrows indicate the time of early harvest, late harvest and final harvest

during the summer of 2013, CP content varied between 14.68 and $18.73 \%$ (Table 2), a range that was not significantly different to that obtained following spring drought stress. The response of the two alfalfa cultivars to drought stress applied in summer was again significantly different, and CP content was lower when summer drought stress was severe compared to moderate stress. As before, CP content was higher in Gold Queen alfalfa than in Suntory alfalfa, for all conditions tested. The ANOVA analysis further indicated that as a result of summer drought stress, Gold Queen suffered significantly more than Suntory alfalfa, resulting in a significance for DSxCV (Table 2).

In 2014, the timing of drought stress during spring was varied. A dry period early in spring reduced CP content of alfalfa compared to the optimally watered control, with the exception of the Gold Queen cultivar harvested early, which actually contained a higher ratio of CP compared to the control (Table 2). A period of drought in late spring affected all plots, except for Gold Queen alfalfa harvested early. Natural rainfall without irrigation significantly reduced the $\mathrm{CP}$ content (Table 2). For this experiment ANOVA analysis indicated that the combination of drought stress and harvest time produced significantly different results (a late harvest after late-spring drought produced lowest yields). Likewise, the combined factors of drought stress and cultivar, of harvest time and cultivar, and the combination of all three parameters were all significant. The highest $\mathrm{CP}$ content was obtained with Gold Queen harvested early following a severe drought in early spring. The lowest CP content was obtained with Suntory alfalfa harvested late following a severe drought in late spring. 
Table 2 Crude protein fraction (\%DM) of alfalfa in Experiment l, grown under drought stress during spring (top) and during summer (middle), and in Experiment II (bottom). Means of 4 analyses per plot are shown

\begin{tabular}{|c|c|c|c|c|c|}
\hline \multicolumn{6}{|c|}{ Crude Protein fraction (CP, \%DM) } \\
\hline & \multirow[t]{2}{*}{ Condition } & \multicolumn{2}{|c|}{ Gold Queen alfalfa } & \multicolumn{2}{|l|}{ Suntory alfalfa } \\
\hline & & Early harvest & Late harvest & Early harvest & Late harvest \\
\hline \multirow[t]{6}{*}{ Spring 2013} & Control & $19.60 \pm 0.16^{\mathrm{a}}$ & $18.19 \pm 0.15^{\mathrm{a}}$ & $18.45 \pm 0.12^{\mathrm{a}}$ & $17.17 \pm 0.14^{a}$ \\
\hline & Moderate spring drought & $18.43 \pm 0.17^{\mathrm{a}}$ & $17.69 \pm 0.13^{\mathrm{a}}$ & $17.45 \pm 0.62^{\mathrm{a}}$ & $16.17 \pm 0.24^{a}$ \\
\hline & Severe spring drought & $17.61 \pm 0.17^{b}$ & $15.61 \pm 0.21^{b}$ & $16.48 \pm 0.16^{b}$ & $14.25 \pm 0.19^{b}$ \\
\hline & Control & $20.30 \pm 0.23^{\mathrm{a}}$ & $19.63 \pm 0.27^{\mathrm{a}}$ & $18.68 \pm 0.10^{\mathrm{a}}$ & $18.32 \pm 0.15^{a}$ \\
\hline & Moderate summer drought & $18.73 \pm 0.05^{b}$ & $18.32 \pm 0.08^{b}$ & $17.76 \pm 0.24^{b}$ & $17.31 \pm 0.15^{b}$ \\
\hline & Severe summer drought & $17.33 \pm 0.22^{c}$ & $15.84 \pm 0.35^{c}$ & $16.43 \pm 0.26^{c}$ & $14.68 \pm 0.25^{c}$ \\
\hline \multirow[t]{4}{*}{ Spring 2014} & Control & $18.98 \pm 0.13^{\mathrm{a}}$ & $17.80 \pm 0.19^{\mathrm{a}}$ & $17.97 \pm 0.13^{\mathrm{a}}$ & $16.78 \pm 0.22^{\mathrm{a}}$ \\
\hline & Early spring severe drought & $20.02 \pm 0.25^{b}$ & $16.17 \pm 0.14^{\mathrm{b}}$ & $16.46 \pm 0.21^{b}$ & $14.56 \pm 0.16^{b}$ \\
\hline & Late spring severe drought & $18.65 \pm 0.30^{\mathrm{a}}$ & $15.82 \pm 0.23^{c}$ & $15.49 \pm 0.19^{b}$ & $13.43 \pm 0.24^{c}$ \\
\hline & rainfed & $16.73 \pm 0.25^{c}$ & $15.27 \pm 0.28^{c}$ & $16.21 \pm 0.19^{b}$ & $14.54 \pm 0.16^{b}$ \\
\hline
\end{tabular}

"Superscripts indicate significant differences $(P<0.01)$ per column. Identical superscripts per column indicate there was no significant difference. The same applies to all other tables

\section{Concentration of neutral and acid detergent fiber}

The concentration of neutral detergent fibre (NDF) was higher in Suntory than in Gold Queen alfalfa, but the difference was not significant $(P=0.0908)$. Early harvest resulted in a significantly lower fraction of NDF than late harvest (Table 3). Independently of the time of harvest, the content of NDF was increased by severe drought stress in spring or summer, though a moderate drought during spring or summer had no effect on NDF content. During spring, both an early and a late drought increased the NDF fraction equally (Table 3 ).

The concentration of fibre extracted with acid detergent $(\mathrm{ADF})$ in part followed the same trends as those observed for NDF. ADF was also higher in Suntory than in Gold Queen, and this difference was now significant (Table 4). As was observed for NDF, late harvest increased the fraction of ADF, and both an early and a late period of drought during spring significantly increased the ADF fraction, as shown in Table 4. However, the ADF fraction was reduced under severe drought in spring and after a moderate drought in summer, while a severe drought in summer increased the ADF fraction (Table 4).

\section{Concentration of water-soluble carbohydrates}

The fraction of water-soluble carbohydrates (WSC) was significantly higher in Gold Queen than in Suntory alfalfa under all tested conditions, and late harvest produced higher WSC fractions (Table 5). In Experiment I drought stress did not significantly affect these fractions, but in Experiment II, lower WSC fractions were obtained following a drought period in spring, with the exception of early harvested Suntory (Table 5).

Table 3 Neutral detergent fibre fraction (NDF, expressed as \% DM) of alfalfa in Experiments I and II, means $(n=4)$

\begin{tabular}{|c|c|c|c|c|c|}
\hline \multicolumn{6}{|c|}{ Neutral Detergent Fibre fraction (NDF, \%DM) } \\
\hline & \multirow[t]{2}{*}{ Condition } & \multicolumn{2}{|c|}{ Gold Queen alfalfa } & \multicolumn{2}{|l|}{ Suntory alfalfa } \\
\hline & & Early harvest & Late harvest & Early harvest & Late harvest \\
\hline \multirow[t]{6}{*}{ Spring 2013} & Control & $47.63 \pm 0.27^{a}$ & $49.96 \pm 0.42^{a}$ & $48.93 \pm 0.37^{a}$ & $51.44 \pm 0.17^{a}$ \\
\hline & Moderate spring drought & $45.13 \pm 0.17^{a}$ & $46.16 \pm 0.12^{a}$ & $46.93 \pm 0.27^{a}$ & $50.44 \pm 0.67^{a}$ \\
\hline & Severe spring drought & $50.54 \pm 0.21^{b}$ & $55.14 \pm 0.41^{b}$ & $50.39 \pm 0.32^{b}$ & $54.37 \pm 0.65^{b}$ \\
\hline & Control & $47.03 \pm 0.32^{a}$ & $50.25 \pm 0.27^{\mathrm{a}}$ & $47.58 \pm 0.21^{a}$ & $50.93 \pm 0.27^{a}$ \\
\hline & Moderate summer drought & $47.92 \pm 0.44^{\mathrm{a}}$ & $50.15 \pm 0.52^{a}$ & $47.99 \pm 0.63^{a}$ & $51.59 \pm 0.51^{\mathrm{a}}$ \\
\hline & Severe summer drought & $50.33 \pm 0.24^{b}$ & $55.35 \pm 0.30^{b}$ & $50.97 \pm 0.65^{b}$ & $55.84 \pm 0.64^{b}$ \\
\hline \multirow[t]{4}{*}{ Spring 2014} & Control & $44.99 \pm 0.47^{a}$ & $47.74 \pm 0.55^{\mathrm{a}}$ & $45.51 \pm 0.22^{a}$ & $49.67 \pm 0.18^{a}$ \\
\hline & Early spring severe drought & $48.37 \pm 0.34^{b}$ & $53.30 \pm 0.48^{b}$ & $49.22 \pm 0.25^{b}$ & $52.58 \pm 0.54^{b}$ \\
\hline & Late spring severe drought & $48.89 \pm 0.31^{b}$ & $53.46 \pm 0.50^{b}$ & $49.84 \pm 0.48^{b}$ & $53.28 \pm 0.55^{b}$ \\
\hline & rainfed & $44.43 \pm 0.52^{a}$ & $49.09 \pm 0.45^{c}$ & $45.74 \pm 0.35^{\mathrm{a}}$ & $49.70 \pm 0.22^{a}$ \\
\hline
\end{tabular}


Table 4 Acid detergent fibre fraction (ADF, expressed as \% DM) of alfalfa in in Experiments I and II, means $(n=4)$

\begin{tabular}{|c|c|c|c|c|c|}
\hline \multicolumn{6}{|c|}{ Acid Detergent Fibre fraction (ADF, \%DM) } \\
\hline & \multirow[t]{2}{*}{ Condition } & \multicolumn{2}{|c|}{ Gold Queen alfalfa } & \multicolumn{2}{|l|}{ Suntory alfalfa } \\
\hline & & Early harvest & Late harvest & Early harvest & Late harvest \\
\hline \multirow[t]{6}{*}{ Spring 2013} & Control & $34.52 \pm 0.33^{\mathrm{a}}$ & $36.23 \pm 0.29^{\mathrm{a}}$ & $36.15 \pm 0.47^{\mathrm{a}}$ & $37.67 \pm 0.40^{\mathrm{a}}$ \\
\hline & Moderate spring drought & $33.12 \pm 0.37^{\mathrm{a}}$ & $35.23 \pm 0.73^{\mathrm{a}}$ & $35.15 \pm 0.17^{\mathrm{a}}$ & $36.67 \pm 0.49^{a}$ \\
\hline & Severe spring drought & $32.25 \pm 0.27^{b}$ & $33.73 \pm 0.30^{\mathrm{b}}$ & $34.23 \pm 0.40^{b}$ & $34.09 \pm 0.38^{b}$ \\
\hline & Control & $35.36 \pm 0.35^{\mathrm{a}}$ & $38.66 \pm 0.26^{a}$ & $36.69 \pm 0.40^{\mathrm{a}}$ & $39.51 \pm 0.24^{\mathrm{a}}$ \\
\hline & Moderate summer drought & $32.83 \pm 0.18^{b}$ & $34.49 \pm 0.22^{b}$ & $34.91 \pm 0.34^{b}$ & $36.07 \pm 0.43^{b}$ \\
\hline & Severe summer drought & $38.70 \pm 0.31^{c}$ & $42.64 \pm 0.32^{c}$ & $39.90 \pm 0.35^{c}$ & $43.66 \pm 0.17^{c}$ \\
\hline \multirow[t]{4}{*}{ Spring 2014} & Control & $36.51 \pm 0.37^{\mathrm{a}}$ & $39.66 \pm 0.23^{\mathrm{a}}$ & $37.93 \pm 0.34^{\mathrm{a}}$ & $40.41 \pm 0.32^{\mathrm{a}}$ \\
\hline & Early spring severe drought & $38.73 \pm 0.23^{b}$ & $40.82 \pm 0.24^{\mathrm{a}}$ & $38.97 \pm 0.26^{b}$ & $42.83 \pm 0.32^{b}$ \\
\hline & Late spring severe drought & $39.82 \pm 0.14^{c}$ & $43.93 \pm 0.32^{\mathrm{b}}$ & $40.14 \pm 0.20^{c}$ & $43.64 \pm 0.19^{c}$ \\
\hline & rainfed & $36.24 \pm 0.32^{\mathrm{a}}$ & $38.90 \pm 0.20^{\mathrm{a}}$ & $37.27 \pm 0.63^{\mathrm{a}}$ & $40.00 \pm 0.51^{\mathrm{a}}$ \\
\hline
\end{tabular}

\section{Hay yield reduction}

At the end of the experiment all plant material was cut $3 \mathrm{~cm}$ above the surface and dried. Hay yields in Gold Queen alfalfa and Suntory alfalfa were reduced by all water-restricted conditions (Table 6), with a reduction between 27\% (rain fed) and 83\% (Gold Queen alfalfa, draught in late spring).

\section{Discussion}

The field experiments described here were conducted to assess the effect of water restriction regimes on two alfalfa cultivars, by the use of fixed and mobile rain shelters. The validity of such an approach to study microclimate effects has been convincingly demonstrated before [20]. We are aware that the shelters may have increased the temperature above ground, especially during hot days in summer, which may have affected plant development [21], as it would add heat stress to the plants in addition to drought stress. Experiments conducted in winter would not suffer from this combined effect, possibly resulting in smaller changes, for instance like those reported for grain yield studied in winter wheat $[22,23]$. However, since reduced rainfall as a result of local climate changes often coincides with higher than normal temperatures, we believe our experimental conditions sufficed to investigate their combined effect. Although temporarily increased day temperatures might have negatively affected the growth and yield of alfalfa, water limitation was most likely the main driver of the observed changes. Irrespective of the water supply treatment, the analytical data of the harvested alfalfa resulted in a predictive nutritive value comparable to data described in the literature [14, 24]. With the obtained values, the harvested alfalfa could be considered a moderate to high quality feed $[25,26]$. Under optimal water conditions, the parameters for feed quality were better for Gold Queen alfalfa than for Suntory alfalfa, with higher protein and lower fiber contents, though the higher water-soluble carbohydrate fraction in Gold Queen could be considered less beneficial.

Table 5 Water-soluble carbohydrate fraction (\%DM) of alfalfa in in Experiments I and II, means $(n=4)$

\begin{tabular}{|c|c|c|c|c|c|}
\hline \multicolumn{6}{|c|}{ Water-soluble carbohydrate fraction (WSC, \%DM) } \\
\hline & \multirow[t]{2}{*}{ Condition } & \multicolumn{2}{|c|}{ Gold Queen alfalfa } & \multicolumn{2}{|l|}{ Suntory alfalfa } \\
\hline & & Early harvest & Late harvest & Early harvest & Late harvest \\
\hline \multirow[t]{6}{*}{ Spring 2013} & Control & $6.58 \pm 0.04^{a}$ & $6.84 \pm 0.02^{a}$ & $6.40 \pm 0.04^{a}$ & $6.72 \pm 0.48^{a}$ \\
\hline & Moderate spring drought & $6.52 \pm 0.14^{a}$ & $6.74 \pm 0.92^{a}$ & $6.40 \pm 0.14^{a}$ & $6.69 \pm 0.41^{a}$ \\
\hline & Severe spring drought & $6.53 \pm 0.03^{a}$ & $6.83 \pm 0.02^{a}$ & $6.38 \pm 0.03^{a}$ & $6.70 \pm 0.05^{a}$ \\
\hline & Control & $6.52 \pm 0.03^{a}$ & $6.83 \pm 0.01^{a}$ & $6.38 \pm 0.02^{a}$ & $6.66 \pm 0.05^{a}$ \\
\hline & Moderate summer drought & $6.52 \pm 0.03^{a}$ & $6.82 \pm 0.02^{a}$ & $6.38 \pm 0.02^{a}$ & $6.66 \pm 0.05^{a}$ \\
\hline & Severe summer drought & $6.57 \pm 0.04^{a}$ & $6.87 \pm 0.02^{\mathrm{a}}$ & $6.50 \pm 0.06^{b}$ & $6.74 \pm 0.05^{\mathrm{a}}$ \\
\hline \multirow[t]{4}{*}{ Spring 2014} & Control & $6.5 \pm 0.03^{a}$ & $6.82 \pm 0.02^{\mathrm{a}}$ & $6.36 \pm 0.03^{a}$ & $6.70 \pm 0.04^{\mathrm{a}}$ \\
\hline & Early spring severe drought & $6.34 \pm 0.02^{b}$ & $6.71 \pm 0.02^{b}$ & $6.31 \pm 0.04^{a}$ & $6.55 \pm 0.05^{b, c}$ \\
\hline & Late spring severe drought & $6.28 \pm 0.02^{b}$ & $6.62 \pm 0.03^{c}$ & $6.30 \pm 0.03^{a}$ & $6.46 \pm 0.07^{c}$ \\
\hline & rainfed & $6.48 \pm 0.03^{a}$ & $6.80 \pm 0.02^{a}$ & $6.33 \pm 0.03^{a}$ & $6.66 \pm 0.04^{a, b}$ \\
\hline
\end{tabular}


Table 6 Hay yield reduction (\%) as a result of drought stress at the end of the experiments

\begin{tabular}{|c|c|c|c|c|c|}
\hline \multirow[t]{2}{*}{ Experiment } & \multirow[t]{2}{*}{ Condition } & \multicolumn{2}{|c|}{$\begin{array}{l}\text { Yield of Gold } \\
\text { Queen hay }\end{array}$} & \multicolumn{2}{|c|}{$\begin{array}{l}\text { Yield of } \\
\text { Suntory hay }\end{array}$} \\
\hline & & $\begin{array}{l}\text { Hay yield } \\
\text { (kg/ha) }\end{array}$ & $\Delta \%$ & $\begin{array}{l}\text { Hay yield } \\
\text { (kg/ha) }\end{array}$ & $\Delta \%$ \\
\hline \multirow[t]{5}{*}{ Experiment I } & Control & $137.3^{\mathrm{a}}$ & n.a. & $125.3^{\mathrm{a}}$ & n.a. \\
\hline & $\begin{array}{l}\text { Moderate spring } \\
\text { drought }\end{array}$ & $52.6^{b}$ & $-54 \%$ & $44.3^{b}$ & $-65 \%$ \\
\hline & $\begin{array}{l}\text { Severe spring } \\
\text { drought }\end{array}$ & $63.7^{\mathrm{b}}$ & $-66 \%$ & $54.6^{b}$ & $-69 \%$ \\
\hline & $\begin{array}{l}\text { Moderate summer } \\
\text { drought }\end{array}$ & $138.4^{b}$ & $-4 \%$ & $123.4^{\mathrm{a}}$ & n.s. \\
\hline & $\begin{array}{l}\text { Severe summer } \\
\text { drought }\end{array}$ & $56.7^{c}$ & $-57 \%$ & $46.7^{c}$ & $-45 \%$ \\
\hline \multirow[t]{4}{*}{ Experiment II } & Control & $138.7^{\mathrm{a}}$ & n.a. & $118.7^{\mathrm{a}}$ & n.a. \\
\hline & $\begin{array}{l}\text { Early spring } \\
\text { severe drought }\end{array}$ & $64.8^{d}$ & $-70 \%$ & $44.8^{\mathrm{b}}$ & $-70 \%$ \\
\hline & $\begin{array}{l}\text { Late spring } \\
\text { severe drought }\end{array}$ & $43.7^{c}$ & $-83 \%$ & $32.7^{c}$ & $-79 \%$ \\
\hline & rainfed & $100.6^{b}$ & $-27 \%$ & $100.6^{b}$ & $-27 \%$ \\
\hline
\end{tabular}

n.a not applicable

The fraction of crude protein was reduced as a result of drought, with a similar decrease in both cultivars, although CP content remained higher in Gold Queen than in Suntory. The CP fraction generally depends on the amount of available $\mathrm{N}[1,27]$ and alfalfa is particularly effective in $\mathrm{N}$-fixation. When the $\mathrm{N}$ fixation performance of alfalfa was determined, it produced 10 to $30 \%$ higher fixation levels than other legumes [28]. Thus, the degree of nitrogen fixation determines the availability of $\mathrm{N}$ for protein production, but it is not the only limiting factor for biomass production: obviously, this is also determined by water availability. Experiments with soybean identified $\mathrm{N}$ uptake as an important factor for biomass production under drought [15], and peanut plants decreased their $\mathrm{N}$ fixation under drought stress [29]. We interpret the decrease in $\mathrm{CP}$ fractions in drought-stressed alfalfa to be caused by a combined stress response to water limitation in addition to a decrease in $\mathrm{N}$ fixation.

The content of neutral fiber increased under strong drought stress, a change that was also observed for acidextracted fiber under certain conditions, though mixed results were obtained for the latter. Fiber concentration is influenced by many interacting factors, such the phase of plant development, leaf-to-stem ratio, environmental conditions (water, temperature, available light etc.), and the availability of nutrients [24-26]. The increase in NDF and ADF fractions under stress is not supported by findings in the literature, where a delayed maturity under drought was reported, associated with lower NDF and ADF concentrations [14, 25]. The major difference between the NDF and the ADF fraction is that the former included hemicellulose (the other main components are cellulose and lignin for both fractions), and the stronger and more consistent increase of the NDF as a result of drought stress in alfalfa suggests that production of hemicellulose is most affected by water restriction. However, results on the effects of drought on hernicellulose concentrations are inconsistent in the literature, as some authors have reported decreased hemicellulose concentration under drought, while other reported an increase [30]. We found that the ADF concentration was consistently lower than that of NDF, a finding that has been reported for other legumes and for most grasses as well [26]. A lower fiber concentration is generally considered beneficial, as it may lead to a higher herbage intake and to an increase in digestibility of forage. An early harvest resulted in lower fiber content and this, combined with a higher protein content, suggests that harvesting early in the season may improve the quality of the alfalfa, particularly after drought.

The fraction of WSC was least affected by drought stress, producing only a minor decrease as a result of drought stress in spring, although others have reported an increase as a result of drought in other plant species $[15,31]$. Gold Queen alfalfa contained significantly higher fractions of WSC, which might explain why it was also generally more capable to cope with drought stress. A high WSC concentration in plants would result in a higher osmotic potential, which drives the uptake of soil water and is therefore of importance to minimize drought stress effects [32]. This osmotic adjustment is a physiological mechanism in response to drought [15], but in our experiments the WSC content changed marginally, only producing a significant decrease during spring drought.

Without irrigation, yields were low and nutritional parameters poor, as demonstrated by the samples grown under natural rainfall. When water supply is limited and continuous irrigation may not be possible, the timing of irrigation needs to be carefully considered. Our results indicate that the most beneficial effect can be expected if irrigation prevents a severe drought in late spring.

Digestibility of fodder may decrease under strong drought stress due to a tendency to lower WSC and higher fiber fractions, and combined with lower protein content this would reduce the nitritive value. However, the decreased protein-to-fiber ratio in alfalfa following a drought would result in a decrease of nitrogen secretion in the urine of ruminants [20], which can be considered beneficial for the environment. The choice of cultivar (Gold Queen) and an early harvest can minimize drought effects. Animal experiments need to be performed to further assess the feed-to-weight conversion and waste production of alfalfa grown under drought stress. 


\section{Conclusions}

The production of alfalfa is a main agricultural activity in areas in China where relatively sandy and infertile soils limit other crops to be produced, but in particular these areas are expected to suffer from increased periods of drought as a result of climate change. It is therefore important to anticipate possible changes in the nutritive value of alfalfa as a result of drought stress. We have demonstrated that only severe drought stress has an impact on yield and composition of alfalfa. Strong drought led to a decrease in hay yield, a decrease in CP content, and an increase in fibre. These effects might in combination decrease the digestibility of the herbage. However, as the ratio of CP to WSC decreased under drought, this could reduce the $\mathrm{N}$ surplus in ruminates. We observed differences between the two tested alfalfa cultivars, both in their performance under optimal water supply and in their response to drought stress, with Gold Queen performing better than the Suntory cultivar. Finally, an early harvest could minimize the effects of drought. The reported findings may assist farmers in choosing the best cultivar, irrigation strategy and harvesting time, to mitigate the effect of decreased precipitation that can be expected in the future.

\section{Additional file}

Additional file 1: Figure S1. Air temperature and rainfall in the 2 years during the experiments were conducted. (DOCX $104 \mathrm{~kb}$ )

\section{Abbreviations}

ADF: Acid detergent fibre; CP: Crude protein; DM: Dry mass; NDF: Neutral detergent fibre; NIRS: Near infrared reflectance spectroscopy; WSC: Water soluble carbohydrates

\section{Acknowledgements}

We are most grateful to all community members in the study region for their time and their confidence in our research. We also sincerely thank the staff of the provincial health department in Chifeng. The support of Zhu GD, Wang Mingchao, Fan Wenqiang, and Cheng Qiming for their help with the field experiments is gratefully acknowledged.

\section{Funding}

This work was supported by the National Natural Science Foundation of China (Grant No. 31360585). Inner Mongolia Agricultural University receives strategic funding from National Natural Science Foundation of China. The funding body had no role in the design of the study and collection, analysis, and interpretation of data and in writing the manuscript.

\section{Availability of data and materials}

The datasets used and/or analysed during the current study are available from the corresponding author on reasonable request.

\section{Authors' contributions}

LYH and JYS conceived the study. GGT and LYH designed the experiments. WQ performed the fieldwork. HGD supervised the fieldwork. WQ performed the quantitative data analysis. LYH wrote the manuscript. All authors read and approved the final manuscript.

\section{Ethics approval and consent to participate}

The seeds were kindly provided by the College of Agriculture and Animal Husbandry, ChiFeng, China. The experimental research on plants, including collection of plant material, complied with institutional, national, or international guidelines and complied with the Convention on the Trade in Endangered Species of Wild Fauna and Flora. These two materials have been deposited in a publicly available herbarium. All field experiments were conducted in accordance with Environmental Protection law of the People's Republic of China and did not involve endangered or protected species.

Consent for publication

Not applicable

\section{Competing interests}

All authors declare that they have no competing interests.

\section{Publisher's Note}

Springer Nature remains neutral with regard to jurisdictional claims in published maps and institutional affiliations.

\section{Author details}

${ }^{1}$ Key Laboratory of Forage Cultivation, Processing and High Efficient Utilization, Ministry of Agriculture, Erdos Street 29, Saihan District, Hohhot 010019, China. ${ }^{2}$ Laboratory of Grassland Resources, Ministry of Education, Erdos Street 29, Saihan District, Hohhot 010019, China. ${ }^{3}$ College of Grassland, Resources and Environment, Inner Mongolia Agricultural University, Hohhot 010019, China

Received: 17 July 2017 Accepted: 28 December 2017

Published online: 15 January 2018

\section{References}

1. Watson CA, Bengtsson H, Ebbesvik M, Løes A-K, Myrbeck A, Salomon E, et al. A review of farm-scale nutrient budgets for organic farms as a tool for management of soil fertility. Soil Use Manag. 2002;18:264-73.

2. Jensen ES, Hauggaard-Nielsen $\mathrm{H}$. How can increased use of biological $\mathrm{N}_{2}$ fixation in agriculture benefit the environment? Plant Soil. 2003;252:177-86.

3. Crews TE, Peoples MB. Can the synchrony of nitrogen supply and crop demand be improved in legume and fertilizer-based agroecosystems? A review Nutr Cycl Agroecosys. 2005;72:101-20.

4. Heinrich J. The legumes expert forum. Science, economy and societymaking ecosystem services from legumes competitive. Braunschweig: German Agricultural Research Alliance (DAFA); 2012. p. 12-47.

5. Hopkins A, Del Prado A. Implications of climate change for grassland in Europe: impacts, adaptations and mitigation options: a review. Grass Forage Sci. 2007;62:118-26.

6. Alcamo J, Moreno JM, Novaky B. Contribution of working group II to the fourth assessment report of the intergovernmental panel on climate change. Cambridge: Cambridge University Press; 2007. p. 541-80.

7. Schindler U, Steidl J, Muller L, Eulenstein F, Thiere J. Drought risk to agricultural land in northeast and Central Germany. J Plant Nutr Soil Sci. 2007:170:357-62.

8. Trenberth KE. Changes in precipitation with climate change. Clim Res. 2011; 47:123-38.

9. Foulds W. Response to soil moisture supply in three leguminous species I. Growth, reproduction and mortality. New Phytol. 1978;80:535-45.

10. Farooq M, Wahid A, Kobayashi N, Fujita D, Basra SM. A. Plant drought stress: effects, mechanisms and management. Agron Sustain Dev. 2009:29:185-212.

11. Jaleel CA, Manivannan $P$, Wahid A, Faroog M, Al-Juburei HJ, Somasundaram $\mathrm{R}$, et al. Drought stress in plants: a review on morphological characteristics and pigments composition. Int J Agric Biol. 2009;11:100-5.

12. Dierschke H, Briemle G. Kulturgrasland. Wiesen, Weiden, und verwandte Staudenfluren. Stuttgart: Ulmer Verlag: 2002. p. 212-7.

13. Marshall AH, Rascle C, Abberton MT, Michaelson-Yeates TPT, Rhodes I. Introgression as a route to improved drought tolerance in white clover (Trifolium repens L.). J Agron Crop Sci. 2001;187:11-8.

14. Peterson PR, Sheaffer CC, Hall MH. Drought effects on perennial forage legume yield and quality. Agron J. 1992;84:774-9.

15. Nakayama N, Saneoka H, Moghaieb REA, Premachandra GS. Response of growth, photosynthetic gas exchange, translocation of ${ }^{13} \mathrm{C}$-labelled photosynthate and N accumulation in two soybean (Glycine max L. Merrill) Cultivars to drought stress. Int J AgricBiol. 2007;9:669-74.

16. Abberton MT, Marshall AH, Michaelson-Yeates TPT, Williams TA, Rhodes I. Quality characteristics of backcross hybrids between Trifolium repens and Trifolium ambiguum. Euphytica. 2002;127:75-80. 
17. Seguin P, Mustafa AF, Sheaffer CC. Effects of soil moisture deficit on forage quality, digestibility, and protein fractionation of Kura clover. J Agron Crop Sci. 2002;188:260-6.

18. Sarwar N, Mahmood S, Nisa MU, Bilal MQ. Factors affecting digestibility of feeds in ruminants. Int J Agric Biol. 1999;1:366-72.

19. Payne. Gene expression profiling in aspergillus flavus. Mycopathologia. 2002;155:13.

20. Moorby JM, Evans RT, Scollan ND, MacRae JC, Theodorou MK. Increased concentration of water-soluble carbohydrate in perennial ryegrass (Lolium perenne L.). Evaluation in dairy cows in early lactation. Grass Forage Sci. 2006;61:52-9.

21. Brisson N, Casals ML. Leaf dynamics and crop water status throughout the growing cycle of durum wheat crops grown in two contrasted water budget conditions. Agron Sustain Dev. 2005;25:151-8.

22. Porter JR, Gawith M. Temperatures and the growth and development of wheat: a review. Eur J Agron. 1999:10:23-36.

23. Mu H, Jiang D, Wollenweber B, Dai T, Jing Q, Cao W. Long-term low radiation decreases leaf photosynthesis, photochemical efficiency and grain yield in winter wheat. J Agron Crop Sci. 2010;196:38-47.

24. Fulkerson WJ, Neal JS, Clark CF, Horadagoda A, Nandra KS, Barchia I. Nutritive value of forage species grown in the warm temperate climate of Australia for dairy cows: grasses and legumes. Livest Sci. 2007;107:253-64.

25. Buxton DR. Quality-related characteristics of forages as influenced by plant environment and agronomic factors. Anim Feed Sci Tech. 1996;59:37-49.

26. Schwarz FJ. Rinderfütterung. In: Kirchgeßner M, Roth FX, Schwarz FJ, Stang Gl, editors. Tierernährung. Frankfurt: DLG-Verlag, Frankfurt am Main; 2008. p. 351-498.

27. Zahran HH. Rhizobium-legume symbiosis and nitrogen fixation under severe conditions and in an arid climate. Microbiol Mol Biol Rev. 1999:63:968-89.

28. Gierus M, Kleen J, Loges R, Taube F. Forage legume species determine the nutritional quality of binary mixtures with perennial ryegrass in the first production year. Anim Feed Sci Tech. 2013;172:150-61.

29. Pimratch S, Jogloy S, Vorasoot N, Toomsan B, Kesmala T, Patanothai A, et al, Association of nitrogen fixation to water uses efficiency and yield traits of peanut. Int J Plant Prod. 2013;7:225-41.

30. Al-Hakimi AMA. Counteraction of drought stress on soybean plants by seed soaking salicylic acid. Int J Bot. 2006;2:421-6.

31. Da Costa M, Huang B. Osmotic adjustment associated with variation in bentgrass tolerance to drought stress. J Amer Soc Hort Sci. 2006;131:338-44.

32. Morgan JM. Osmoregulation and water stress in higher plants. Ann Rev Plant Physio. 1984;35:299-319.

\section{Submit your next manuscript to BioMed Central and we will help you at every step:}

- We accept pre-submission inquiries

- Our selector tool helps you to find the most relevant journal

- We provide round the clock customer support

- Convenient online submission

- Thorough peer review

- Inclusion in PubMed and all major indexing services

- Maximum visibility for your research

Submit your manuscript at www.biomedcentral.com/submit

) Biomed Central 